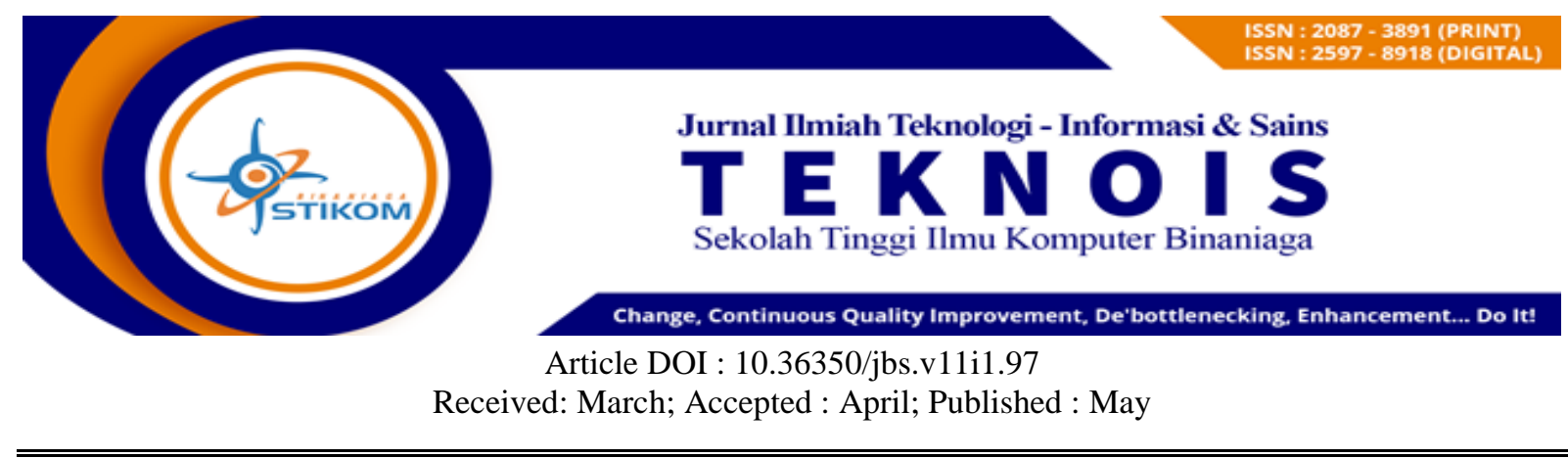

\title{
Maturity Evaluation of Information Technology Governance at PT Insurance XXX Using the DSS02 and DSS03 domain Cobit 5 Framework
}

\author{
Cahyono Budy Santoso \\ Sistem Informasi/STIKOM Binaniga \\ Email: cahyono@stikombinaniaga.ac.id
}

\begin{abstract}
$P T$ Asuransi XXX is one of the largest national general insurance companies in Indonesia, which since its inception was focused on the oil and gas industry. As time goes by and the development of the business world, XXX insurance company responds to market challenges by expanding its business to segments outside the oil and gas industry, including aviation, chemical \& petrochemical, power generation, mining and manufacturing, both conventional and sharia-based businesses. Supporters of the company's operational development have implemented a reliable application system. In its development, this system needs to be managed for service request management, incidents and management, because this system is getting bigger, more complex and the number of users is increasing. To measure however great the quality of service, ongoing information is needed an audit method that can measure whether the services provided have been running well, effectively and efficiently. COBIT 5.0 DSSO2 and DSSO3 domains are used as methods to measure whether the level of IT service demand management capabilities, incidents in managing problems with the system, has been running effectively and optimally. From the measurement results of all these processes, it can be seen that the DSSO2 and DSSO3 levels are at level 2 (managed).
\end{abstract}

Keywords: Insurance; Cobit 5; DSSO2; DSSO3.

\section{A. Introduction}

\section{Background Problem}

The use of information technology (IT) is now a basic requirement of every organization to support its business continuity. The existence of IT itself can make an organization have work effectiveness and efficiency. IT has various benefits for organizations, along with some of the benefits, namely eliminating the meaning of distance in running a business, improving the quality of decision making, improving organizational performance by digitizing business processes, increasing the quality and accuracy of work assignments, and increasing the competitiveness of the organization or company [1].

But on the other hand, unplanned IT implementation can make IT investment fail and lead to wasteful IT investment for the organization or company [2]. No wonder if this happens, the management in the organization or company is reluctant to spend large costs on IT. To avoid this, good information technology governance is required. The implementation of information technology governance will enable an organization or company to ensure the effectiveness and efficiency of IT use, minimize the risk of IT implementation failure and ensure that the IT investment incurred is proportional to the benefits of IT to achieve business goals. 
In its development, the last few years Insurance XXX has experienced very rapid growth. This is indicated by the growth in assets, premium income and profits earned by the company. Established on 25 November 1981, Insurance XXX is a general insurance company headquartered in Jakarta. Judging by the number of articles of association of the company, Insurance XXX has a scope of activities in the general insurance, reinsurance, and sharia business sectors. The company prioritizes innovation in product excellence and develops integrated technology to provide maximum service to every customer in every region in Indonesia. Currently the company has taken advantage of the existence of information technology to support its business needs. In addition, to manage all information technology needs used. Within the company, many business processes have used an integrated loss insurance information system in the form of web and mobile applications.

But on the other hand, so far the use of IT in companies still has shortcomings and problems that interfere with company business. The following is a list of IT-related problems that are still being faced by the company (Figure 1)

Seeing the picture above, $56 \%$ of the IT incident problems found in companies are IT infrastructure problems such as problems that cannot print, computer hangs, monitors are off, internet is slow, email is slow, email capacity is full, network connection is down or slow, computers are not normal, printers abnormal, public drive capacity is full and there is no control over the use of external devices such as USB flash drives and hard drives. In addition, there were $44 \%$ problems related to the use and development of applications such as application login errors, processing and data input errors, application report errors and data discrepancies in the report.

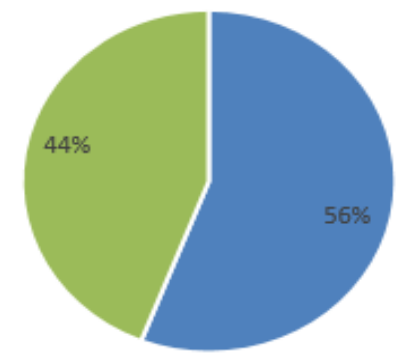

- Application . = Infrastruktur

Figure 1. IT Incidents in XXX Insurance Company

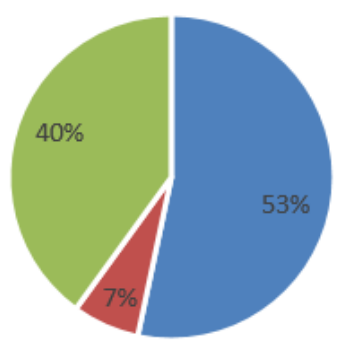

- Application - Database | Infrastructure

Figure 2. IT Problems in XXX Insurance Company

Seeing the picture above, 53\% of IT problems found in companies are IT application problems, such as minor or major application bugs that disrupt operations. In addition, there are infrastructure problems as much as $40 \%$, such as email, computer, printer, network problems that are minor or major that disrupt operations. For database problems as much as $7 \%$ such as database performance problems, database login access and database capacity.

Seeing the above problems, it can be said that the problem that occurs is the problem of business operation disruption related to the problem of using information technology, both applications and infrastructure. For companies that have a target of winning the insurance business competition in 2020 and the following years, IT problems must be minimized and prevented so that the existence and use of IT in the company can be optimal and can support the company in achieving its business goals.

This study aims to analyze IT governance and measure the maturity level of IT governance in XXX Insurance. By measuring the maturity level of IT governance owned by the company, the company will be able to ascertain whether the IT owned is in accordance with the needs and has an effective and efficient impact. Information technology management problems can be minimized and prevented where indirect losses due to investment and information technology problems do not occur so that the company's business processes are not disrupted 
and the company's business objectives can be achieved with mature IT governance. In addition, it is hoped that the above problems can also be reduced or even prevented.

To ensure effective and efficient management of information technology, it is necessary to evaluate the performance of information technology (IT) governance. There are several frameworks that can be used to evaluate the performance of IT governance, namely COBIT, COSO, ITIL, ISO and others. In this study COBIT 5 was chosen as the reference framework because COBIT 5 is a comprehensive framework and provides guidelines for holistic IT management that can make IT provide optimal value by paying attention to several aspects of IT ranging from human resources, skills, competencies, services, infrastructure and applications is a component of IT governance.

\section{Theoretical Foundation}

a. Framework Cobit

COBIT (Control Objective for Information and related Technology) is a collection of documentation and guidelines for implementing IT Governance, a framework that helps auditors, management and users to bridge the gap between business risks, control needs and technical issues. COBIT was developed by the IT Governance Institute (ITGI) which is part of the Information System Audit and Control Association (ISACA. 2012). COBIT 5.0 helps enterprises build optimal value from IT by managing a balance between benefit realization and optimization. Risk level and resource use. COBIT 5 allows information and related technology to be managed holistically for the entire enterprise, covering the business and functional areas as a whole, taking into account the benefits of IT for internal and external stakeholders.

b. Cobit 5 Principles

According to ISACA (2012), that COBIT 5.0 has 5 basic principles:

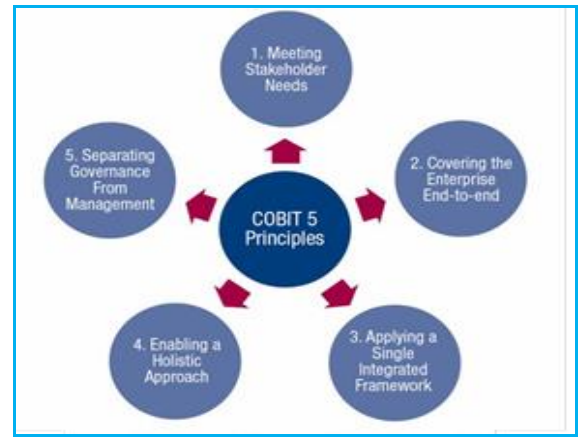

Figure 3. COBIT 5 Principles [8]

1) Meeting Stakeholder Needs.

2) Covering to Enterprise End-to-End.

3) Applying a single Framework.

4) Enabling a Holistic Approach.

5) Separating Governance from Management.

c. Capability Level Process

In assessing the maturity or Maturity Model of IT governance, COBIT 5 uses the Capability Model. In this capability model there are 6 levels, that is : Level 0 (Incomplete Process), Level 1 (Performed Process), Level 2 (Managed Process), Level 3 (Established Process), Level 4 (Predictable Process) and Level 5 (Optimizing Process).

\section{d. Related Reasearch}

In this study, the author has several related studies that are used as a reference. The following is a summary of several studies related to the use of COBIT 5 to correct and resolve IT governance problems:

In this paper [3], the authors evaluate the implementation of digitalization management on the Indonesian National Library in Jakarta. Namely by using COBIT 5 on the DSS04, 
DSS05, and DSS06 domains. The results show that the DSS01, DSS02 and DSS03 scores are at level 1 while DSS04, DSS05 and DSS06 are at level 2.

The related research further conducts IT governance audits using the COBIT 5 framework which is focused on the DSS03 domain [9]. Based on the research results, DSS03 in the company has a capability level of $64.66 \%$ with the status of Partially Achieved. In addition, the authors also provide recommendations to increase the level of capability to the level that is expected to be used by PT. DEF to maximize their IT governance.

In this paper [10], we can look at the use of COBIT 5 in IT governance assessment in an academic context. Research aims to assess the effectiveness of IT governance implementation at Atma Jaya Yogyakarta University using COBIT 5. The domains used in this study are DSS, BAI and APO. The results of this study indicate that the maturity level of IT governance at Atma Jaya Yogyakarta University is at level 3.

In this study [11] aims to measure the maturity level of project management in financial companies, and recommend the implementation of best practices in project management of these companies. The method used by the author is to map business goals, enabler goals, IT related goals and the Cobit 5 process. There are 9 COBIT 5 domains obtained from the mapping results, namely EDM02, APO09, APO11, BAI01, BAI02, BAI03, BAI04, BAI08, and MEA02. As a result of the measurements, it was found that most of the measurements were at level 1.

From several studies related above, it can be said that COBIT 5 can be used to improve information technology governance in various fields. According to the author, COBIT 5 is a frame of reference in writing research related to the evaluation of information technology governance performance in XXX Insurance. The author hopes that this research can help companies improve the quality of existing information technology governance to support companies achieving their business goals using IT. Effectively and efficiently.

\section{B. METHODE}

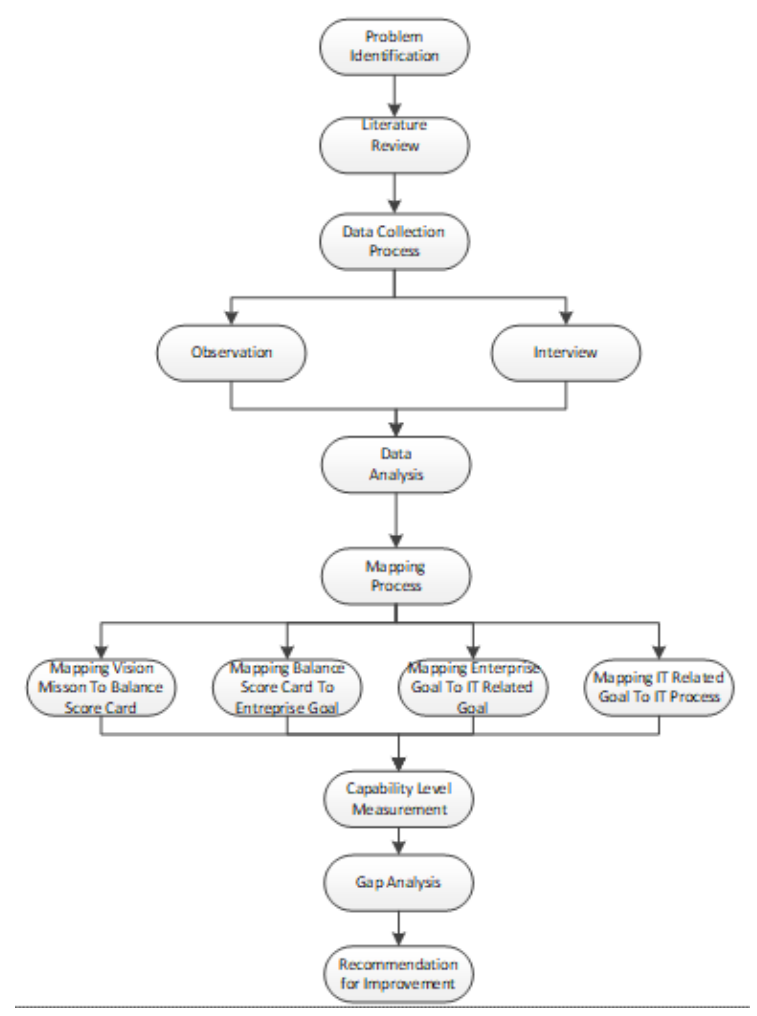

Figure 4. Research Methodology 


\section{Problem Identification}

At this stage the writer will identify the problem from the analysis of IT governance management in Insurance XXX now. Problem identification was carried out by interviewing several IT sources from 4 departments, namely the department of infrastructure, applications, support services and business analysis in the company, in addition to interviews the author also made observations to see the condition of information technology governance owned by the company.

From the results of the identification of the problems carried out, here are the IT problems facing the company:

Tabel 1. Problem List

\begin{tabular}{|r|l|}
\hline No & Problem \\
\hline 1 & The classification scheme and priority of service requests are incomplete \\
\hline 2 & Not all of the Service Level Agreements (SLA) for each incident are defined. \\
\hline 3 & Classification of problems and incidents that come have not been properly managed. \\
\hline 4 & There is no determination of incident levels, especially for large and critical incidents, for example incidents \\
\hline 5 & Reports and distribution of reports regarding incidents have not been carried out in a timely manner. \\
\hline 6 & There is no trend of incidents that have emerged and patterns of problems. \\
\hline 7 & Not all of them have defined SLAs for priority incident services based on urgency and business impact \\
\hline 8 & The formation of a support group to help identify and analyze the root of the problem has not been intensively \\
\hline 9 & Some incidents occur repeatedly and the solutions that are implemented are temporary solutions, not \\
\hline 10 & The resolution for incident resolution is not written in full, so it cannot be used as knowledge for similar cases \\
\hline 11 & User feedback on the level of satisfaction in solving the incident or problem is quite low \\
\hline 12 & Not all of them have recorded the identification of the root of the problem and the solution \\
\hline 13 & There is no report on the suitability of handling problems with the needs and Service Level Agreement. \\
\hline 14 & There has been no optimization of the use of existing resources for handling problems. \\
\hline 15 & The list of incidents and the list of solution databases for dealing with them is incomplete and has not been \\
\hline 16 & Not everything has been communicated to the relevant user for any problem solving \\
\hline 17 & Not all of them have monitored problem resolution with business requests and SLAs \\
\hline
\end{tabular}

\section{Literature Review}

The next stage is the literature study, the author will study and collect research related to evaluating the performance of IT governance with COBIT 5. In addition, the author will also study the use of tools such as COBIT 5, balanced scorecard and RACI charts used for the evaluation process of information technology governance.

\section{Data Collection Process}

In collecting data, there are 2 ways that the writer does, namely by observation and interviews. For observations made by the author during this research, it is hoped that the authors can identify the conditions and problems experienced by the company every day and know how the company resolves the problems that occur. The author will conduct interviews with several IT resources in the company, namely the manager of the infrastructure department, applications, service support and business analysts in the Information Technology group.

\section{Data Analisys and Mapping Process}

After all the necessary data is deemed sufficient, the author will begin data processing. In this stage, the first thing to do is to map the company's vision and mission into the COBIT 5 enterprise goals. The next step after obtaining related enterprise goals, the mapping is done again, namely between enterprise goals and IT related goals COBIT 5. Then after knowing the IT related goals owned by the company, the mapping is done again between IT related goals to the IT processes owned by COBIT 5 .

\section{Capability Level Measurement and Gap Analysis}

From the mapping stage, after knowing the related IT processes, then the writer will be able to measure the level of IT capabilities at the current and expected conditions by the company. The current capability level is obtained by adding up the processes per level and divided by the number of processes evaluated. After obtaining the value of the capability level per IT process, then the writer will make a gap analysis. The gap value will be seen after the writer makes a comparison with the spider chart between the capability level of the current condition and the expected capability value. 


\section{Recommendations for Improvement}

In this stage, the authors will provide recommendations for improvement for the processes that are evaluated to support Insurance X. The author will provide recommendations per domain and COBIT 5 process selected. These improvement recommendations will help companies solve existing problems so that corporate IT governance can be effective as expected and according to COBIT 5 standards.

\section{Discussion}

\section{Finding Related COBIT 5 Process}

In mapping the vision and mission to COBIT 5 enterprise goals, the first thing to do is to find out the company's business goals through the vision and mission of the company.

From the vision and mission of company, we can know that the company's business goals are as follows:

a. Creating customer satisfaction

b. Empowering human resources to become professional people

c. Developing an insurance company is the pride of the world-class Indonesia nation

Having known the company's business goals, then we can do the enterprise COBIT goals mapping 5. Below are the results of the mapping that has been done, namely alignment of IT and business strategy, delivery of IT services in line with business requirements, and others as shown in the figure 5 .

\begin{tabular}{|c|c|c|c|}
\hline \multirow{3}{*}{$\begin{array}{l}\text { Mission } \\
\begin{array}{l}\text { Creating customer } \\
\text { satisfaction }\end{array} \\
\end{array}$} & \multirow{2}{*}{\begin{tabular}{|l} 
IT BSC Dimension \\
Financial
\end{tabular}} & \multicolumn{2}{|r|}{ Information and Related Technology Goal } \\
\hline & & $\rho 1$ & Alignment of IT and business strategy \\
\hline & & 02 & IT compliance and support for business compliance with external laws and regulations \\
\hline \multirow{5}{*}{$\begin{array}{l}\text { Empower human } \\
\text { resources to become } \\
\text { professional people }\end{array}$} & & 03 & Commitment of executive management for making IT-related decisions \\
\hline & & 04 & Managed IT-related business risk \\
\hline & & 05 & Realised benefits from IT-enabled investments and services porttolio \\
\hline & & 06 & Transparency of IT costs, benefits and risk \\
\hline & & 07 & Delivery of IT services in line with business requirements \\
\hline \multirow{10}{*}{$\begin{array}{l}\text { Developing an insurance } \\
\text { company is the pride of } \\
\text { the world-class } \\
\text { Indonesian nation }\end{array}$} & & 08 & Adequate use of applications, information and technology solutions \\
\hline & & 09 & IT agility \\
\hline & & 10 & Security of information, processing infrastructure and applications \\
\hline & & 11 & Optimisation of IT assets, resources and capabilities \\
\hline & & 12 & Enablement and support of business processes by integrating applications and technology into business processes \\
\hline & & 13 & Delivery of programmes delivering benefits, on time, on budget, and meeting requirements and quality standards \\
\hline & & 14 & Availability of reliable and useful information for decision making \\
\hline & & 15 & IT compliance with internal policies \\
\hline & Leaming and Growth & 16 & Competent and motivated business and IT personnel \\
\hline & & 17 & Knowledge, expertise and initiatives for business innovation \\
\hline
\end{tabular}

Figure 5. Relation between business goals and enterprise goals

From the mapping results, the author only chose a few processes related to the problems faced by the company that have been described in chapter 3 namely DSS02 (Manage Service Requests and Incidents) and DSS03 (Manage Problems). Below are a table IT Related goals and a table between the relationship between the selected process and the problems faced by the company. P for primary relationship and $\mathrm{S}$ for secondary relationship.

Table 2. IT Related Goals

\begin{tabular}{|l|c|}
\hline \multicolumn{2}{|c|}{ ITRG 07 Delivery of IT services in line vith business requirements } \\
\hline EDM01Ensure Governance Framework Setting and Maintenance & P \\
\hline EDM02 Ensure Benefits Delivery & $\mathrm{P}$ \\
\hline EDM05 Ensure Stakeholder Transparency & $\mathrm{P}$ \\
\hline AP002Manage Strategy & $\mathrm{P}$ \\
\hline AP008 Manage Relationships & $\mathrm{P}$ \\
\hline AP009Manage Service Agreements & $\mathrm{P}$ \\
\hline AP010 Manage Supplies & $\mathrm{P}$ \\
\hline AP011Manage Quality & $\mathrm{P}$ \\
\hline BA102 Manage Requirements Definition & $\mathrm{P}$ \\
\hline BA103 Manage Solutions Identification and Build & $\mathrm{P}$ \\
\hline BA104 Manage Availability andCapacity & $\mathrm{P}$ \\
\hline BA106 Manage Changes & $\mathrm{P}$ \\
\hline DSS01Manage Dperations & $\mathrm{P}$ \\
\hline DSS02 Manage Service Requests and Incidents & $\mathrm{P}$ \\
\hline DSS03 Manage Problems & $\mathrm{P}$ \\
\hline DSS04 Manage Continuty & $\mathrm{P}$ \\
\hline DSS06 Manage Business Process Controls & $\mathrm{P}$ \\
\hline MEA01Monitor, Evaluate and Assess Performance andConformance & $\mathrm{P}$ \\
\hline
\end{tabular}


Volume 11 Number 1 May 2021 Page. 17-26

Journal Homepage : http://teknois.stikombinaniaga.ac.id/index.php/JBS

DOI Link : http://doi.org/10.36350/jbs.v11i1

Table 3. Problem Relation with COBIT 5 Process

\begin{tabular}{|r|l|l|}
\hline No & Problem & Domain \\
\hline 1 & The classification scheme and priority of service requests are incomplete & DSSO2 \\
\hline 2 & Not all of the Service Level Agreements (SLA) for each incident are defined. & DSSO2 \\
\hline 3 & Classification of problems and incidents that come have not been properly managed. & DSSO2,DSS03 \\
\hline 4 & There is no determination of incident levels, especially for large and critical incidents, for example incidents regarding system & DSS02 \\
\hline 5 & Reports and distribution of reports regarding incidents have not been carried out in a timely manner. & DSSO2 \\
\hline 6 & There is no trend of incidents that have emerged and patterns of problems. & DSSO2 \\
\hline 7 & Not all of them have defined SLAs for priority incident services based on urgency and business impact & DSSO2 \\
\hline 8 & The formation of a support group to help identify and analyze the root of the problem has not been intensively carried out. & DSS03 \\
\hline 9 & Some incidents occur repeatedly and the solutions that are implemented are temporary solutions, not permanent solutions & DSSO2 \\
\hline 10 & The resolution for incident resolution is not written in full, so it cannot be used as knowledge for similar cases & DSSO2 \\
\hline 11 & User feedback on the level of satisfaction in solving the incident or problem is quite low & DSSO2 \\
\hline 12 & Not all of them have recorded the identification of the root of the problem and the solution & DSS03 \\
\hline 13 & There is no report on the suitability of handling problems with the needs and Service Level Agreement. & DSS03 \\
\hline 14 & There has been no optimization of the use of existing resources for handling problems. & DSS03 \\
\hline 15 & The list of incidents and the list of solution databases for dealing with them is incomplete and has not been updated regularly. & DSS03 \\
\hline 16 & Not everything has been communicated to the relevant user for any problem solving & DSS03 \\
\hline 17 & Not all of them have monitored problem resolution with business requests and SLAs & DSS03 \\
\hline
\end{tabular}

\section{Assessmentof Selected COBIT 5 Process}

a. DSSO2 manage Service request and Incidents

DSS02 focuses on the request and incident service recovery process, namely recording and fulfilling user requests and incidents, diagnosis, and escalation (if needed) in the process of resolving incidents and requests.

Table 4. DSS02 Capability Level 1 Assessment

\begin{tabular}{|l|l|r|}
\hline DSS02 Manage Service Request and Incidents \\
\hline Governance Practises & Exists & Score \\
\hline DSS02.01 Define incident and service request classification sc & Yes & $100 \% 6$ \\
\hline DSS02.02 Record, classify, and priorities request and incident & Yes & $100 \% 6$ \\
\hline DSS02.03 Verify, approve and fulfil service request & Yes & $100 \% 6$ \\
\hline DSS02.04 Investigate, diagnose and allocate incidents & Yes & $100 \% 6$ \\
\hline DSS02.05 Resolve and recover from incidents & Yes & $100 \% 6$ \\
\hline DSS02.06 Close service request and incidets & Yes & $100 \% 6$ \\
\hline DSS02.07 Track status and produce reports & Yes & $100 \% 6$ \\
\hline \multicolumn{2}{|c|}{ Average Score } & $100 \% 6$ \\
\hline
\end{tabular}

Detail information from the DSS01 capability Level 1 assessment:

1) There is a process of defining incidents and a service request classification scheme

2) There is a process of recording, classifying and prioritizing requests and incidents

3) There is a verification process, approve and fulfill service requests

4) There is a process of investigation, diagnosis and incident allocation

5) There is a process of resolving incidents

6) There is a process of closing service requests and incidents

7) There is a process of tracking status and generating reports

Table 5. DSS Performance Management Assessment

\begin{tabular}{|r|l|l|r|}
\hline \multicolumn{3}{|c|}{ Performance Management } \\
\hline No & Generic Practise & Exits & Score \\
\hline 1 & Identify the Objective & Yes & $100 \%$ \\
\hline 2 & Plan and monitor the performance & Yes & $100 \%$ \\
\hline 3 & Adjust the performance & Yes & $100 \%$ \\
\hline 4 & Define the responsibilities & Yes & $100 \%$ \\
\hline 5 & Identify and make available & Yes & $100 \%$ \\
\hline 6 & Manage the interface Average Score & Yes & $100 \%$ \\
\hline \multicolumn{2}{|c|}{} & $100 \%$ \\
\hline
\end{tabular}

Description of the DSS02 Capability Level 2 Performance Management assessment:

1) Users have understood the importance of managing requests and incidents

2) Performance planning and monitoring has also been accomplished and implemented in a request and incident management document

3) The management of each work performance activity has also been carried out within the company.

4) The duties and responsibilities of each request and incident management activity and process are clearly defined.

5) The resources required to carry out the demand and incident management processes and activities have been identified. Communications have been made to ensure that 
Volume 11 Number 1 May 2021 Page. 17-26

Journal Homepage : http://teknois.stikombinaniaga.ac.id/index.php/JBS

DOI Link : http://doi.org/10.36350/jbs.v11i1

each employee understands their duties and responsibilities in carrying out the request and incident management process.

The assessment process still go on to the next level because it exceeds $85 \%$ [12]. The next assessment is level 2 on work product outputs. Below is the result:

Table 6. DSS02 work product output assessment

\begin{tabular}{|c|c|c|c|}
\hline \multicolumn{4}{|c|}{ DSS02 Manage Service Request and Incidents } \\
\hline Base Practices & Work Product Output & Exists & Score \\
\hline \multirow{3}{*}{$\begin{array}{l}\text { DSS02.01 Define incident and service } \\
\text { request classification schemes }\end{array}$} & $\begin{array}{l}\text { Incidents and services request } \\
\text { classification schemes and } \\
\text { models }\end{array}$ & Yes & 7596 \\
\hline & \begin{tabular}{|l|} 
Rules for incident escalation \\
\end{tabular} & Yes & $75 \%$ \\
\hline & \begin{tabular}{|l|} 
Criteria for problem registration \\
\end{tabular} & Yes & 10096 \\
\hline \multirow[b]{2}{*}{$\begin{array}{l}\text { DSSO2.02 Record, classify, and priorities } \\
\text { request and incidents }\end{array}$} & $\begin{array}{l}\text { Incidents and services request } \\
\log \end{array}$ & Yes & $100 \%$ \\
\hline & $\begin{array}{l}\text { Classified and prioritised } \\
\text { incidents and service request }\end{array}$ & Yes & 7596 \\
\hline \multirow{2}{*}{$\begin{array}{l}\text { DSSO2.03 Verify, approve and fulfil } \\
\text { service request }\end{array}$} & Approved service request & No & $75 \%$ \\
\hline & Fulfilled Service request & Yes & $100 \%$ \\
\hline \multirow{2}{*}{$\begin{array}{l}\text { DSSO2.04 Investigate, diagnose and } \\
\text { allocate incidents }\end{array}$} & Incidents symptoms & Yes & 7596 \\
\hline & Problem log & Yes & 7596 \\
\hline $\begin{array}{l}\text { DSSO2.05 Resolve and recover from } \\
\text { incidents }\end{array}$ & Incidents resolution & Yes & 7596 \\
\hline \multirow[b]{2}{*}{$\begin{array}{l}\text { DSsO2.06 Close service request and } \\
\text { incidets }\end{array}$} & $\begin{array}{l}\text { Closed service request and } \\
\text { incidents }\end{array}$ & Yes & $75 \%$ \\
\hline & $\begin{array}{l}\text { User confirmation of } \\
\text { satisfactory fulfillment or }\end{array}$ & Yes & $50 \%$ \\
\hline \multirow[b]{2}{*}{$\begin{array}{l}\text { DSSO2.07 Track status and produce } \\
\text { reports }\end{array}$} & $\begin{array}{l}\text { Incidents Status and trens } \\
\text { Report }\end{array}$ & Yes & $50 \%$ \\
\hline & $\begin{array}{l}\text { Request Fullfillment status and } \\
\text { trends report }\end{array}$ & & $50 \%$ \\
\hline \multicolumn{3}{|c|}{ Average Score } & $75 \%$ \\
\hline
\end{tabular}

Information from the DSS02 Capability Level 2 assessment Work Product Outputs:

Table 7. DSS02 process assessment result

\begin{tabular}{|c|c|c|c|c|c|c|c|c|c|c|}
\hline \multicolumn{11}{|c|}{ DSS02 Manage Service Request and Incidents } \\
\hline \multirow[t]{3}{*}{ Goal } & \multicolumn{10}{|c|}{$\begin{array}{l}\text { Provide timely and effective response to user request and resolution of all types incidents. Restore } \\
\text { normal service, record and fulfill user request, record, investigate, diagnose, escalate, and resolve } \\
\text { incidents }\end{array}$} \\
\hline & & Level 1 & Level 2 & & Level 3 & & Level 4 & & Level 5 & \\
\hline & Level 0 & PA1.1 & PA2.1 & PA2.2 & PA 3.1 & PA 3.2 & PA 4.1 & PA 4.2 & PA 5.1 & PA 5.2 \\
\hline Rating Percentage & $100 \% 6$ & $100 \%$ & $100 \%$ & $75 \%$ & & & & & & \\
\hline
\end{tabular}

Based on the assessment, this domain is on level 2 with $75 \%$ and status largely achieved. Here are the results of the DSS02 assessment of the company. The assessment process is not continued to the next stage because in this stage is not Fully Achieved (Less than $85 \%)$ [12].

b. DSSO3 Manage Problem

DSS03 focuses on the process of identifying and classifying problems along with root causes, providing permanent solutions to prevent recurring incidents and providing recommendations for improvements.

Detail information from the DSS03 capability Level 1 assessment:

1) There is a problem identification and classification process

2) There is a problem analysis process involving management experts

3) There is a process of identifying the root of the problem and formulating alternative solutions

4) There is a process of identifying the root of the problem and the solution can be a change management process

5) There is an analysis process to see trend indications of problems

Tabel 8. DSS03 capability level 1 assessment

\begin{tabular}{|l|l|r|}
\hline DSS03 Manage Problem & Exists & Score \\
\hline Governance Practises & Yes & $100 \%$ \\
\hline DSS03.01 Identify and classify problems & Yes & $100 \%$ \\
\hline DSS03.02 Investigate and diagnose problems & Yes & $100 \%$ \\
\hline DSS03.03 Raise known error & Yes & $100 \%$ \\
\hline DSS03.04 Resolve and close problem & Yes & $100 \%$ \\
\hline DSS03.05 Perform proactive problem management & $100 \%$ \\
\hline \multicolumn{2}{|c|}{ Average Score } &
\end{tabular}

Tabel 9. DSS03 performance management assessment

\begin{tabular}{|r|l|l|r|}
\hline \multicolumn{2}{|c|}{ Performance Management } & Exits & Score \\
\hline No & Generic Practise & Yes & $100 \%$ \\
\hline 1 & Identify the Objective & Yes & $100 \%$ \\
\hline 2 & llan and monitor the performance & Yes & $100 \%$ \\
\hline 3 & Adjust the performance & Yes & $100 \%$ \\
\hline 4 & Define the responsibilities & Yes & $100 \%$ \\
\hline 5 & Identify and make available & Yes & $100 \%$ \\
\hline 6 & Manage the interface Average Score & $100 \%$ \\
\hline \multicolumn{2}{|l|}{} \\
\hline
\end{tabular}


Volume 11 Number 1 May 2021 Page. 17-26

Journal Homepage : http://teknois.stikombinaniaga.ac.id/index.php/JBS

DOI Link : http://doi.org/10.36350/jbs.v11i1

The assessment process still go on to the next level because it exceeds 85\% [12]. The next assessment is level 2 on work product outputs. Below is the result:

Tabel 10. DSS03 work product output assessment

\begin{tabular}{|c|c|c|c|}
\hline \multicolumn{4}{|c|}{ DSS03 Manage Problem } \\
\hline Base Practices & Work Product Output & Exists & Score \\
\hline \multirow[b]{3}{*}{ DSS03.01 Identify and classify problems } & Problem classification & Yes & $100 \%$ \\
\hline & Problem status report & Yes & $100 \%$ \\
\hline & Problem register & Yes & $100 \%$ \\
\hline \multirow[b]{2}{*}{ DSS03.02 Investigate and diagnose problems } & Root cause of problem & Yes & $50 \%$ \\
\hline & Problem resolution report & Yes & $75 \%$ \\
\hline \multirow[b]{2}{*}{ DSS03.03 Raise known error } & Known error report & No & $50 \%$ \\
\hline & Proposes solution to known error & Yes & $75 \%$ \\
\hline \multirow[b]{2}{*}{ DSS03.04 Resolve and close problem } & Closed problem error & Yes & $75 \%$ \\
\hline & $\begin{array}{l}\text { Communication of knowledge } \\
\text { learned }\end{array}$ & Yes & $75 \%$ \\
\hline \multirow{2}{*}{ DSS03.05 Perform proactive problem manage } & $\begin{array}{l}\text { Problem resolution monitoring } \\
\text { report }\end{array}$ & & $50 \%$ \\
\hline & indetified sustainable solution & Yes & $75 \%$ \\
\hline \multicolumn{3}{|c|}{ Average Score } & $83 \%$ \\
\hline
\end{tabular}

Tabel 11. DSS02 process assessment result

\begin{tabular}{|c|c|c|c|c|c|c|c|c|c|c|}
\hline \multicolumn{11}{|c|}{ DSS03 Manage Problem } \\
\hline \multirow{3}{*}{\begin{tabular}{|l} 
Goal \\
Level
\end{tabular}} & \multicolumn{10}{|c|}{$\begin{array}{l}\text { Identify and classify problem and their root causes and provide timely resolution to prevent recurring } \\
\text { incidents. Provide recommendations for improvement }\end{array}$} \\
\hline & \multirow[b]{2}{*}{ Level 0} & \multirow{2}{*}{\begin{tabular}{|l|} 
Level 1 \\
PA 1.1 \\
\end{tabular}} & \multicolumn{2}{|l|}{ Level 2} & \multicolumn{2}{|l|}{ Level 3} & \multicolumn{2}{|l|}{ Level 4} & \multicolumn{2}{|l|}{ Level 5} \\
\hline & & & PA 2.1 & PA 2.2 & PA 3.1 & PA 3.2 & PA 4.1 & PA 4.2 & PA 5.1 & PA 5.2 \\
\hline Rating Percentage & $100 \%$ & $100 \%$ & $100 \%$ & $83 \%$ & & & & & & \\
\hline
\end{tabular}

Based on the assessment, this domain is on level 2 with $83 \%$ and status largely achieved. Here are the results of the DSS03 assessment of the company. The assessment process is not continued to the next stage because in this stage is not Fully Achieved (Less than $85 \%)$ [12].

\section{Current Capability}

Based on the assessment that have been done, there are 2 processes at level 2 which are DSS02 Manage Service Request and Incident and DSS03 Managed problem. The following table shows the results of the current capability level based on COBIT 5:

Tabel 12. Current capability level

\begin{tabular}{|l|c|c|c|c|c|c|c|}
\hline & \multicolumn{5}{|c|}{ Capability Level } & \\
\cline { 2 - 7 } Cobit 5 Process & Level 0 & Level 1 & Level 2 & Level 3 & Level 4 & Level 5 & Capability Level Name \\
\hline DSS02 & & & V & & & & Managed \\
\hline DSS03 & & & V & & & & Managed \\
\hline & & & & & & & \\
\hline
\end{tabular}

\section{Improvement Recommendation}

In general, after the company makes improvements according to the recommendations of each process, the thing that needs to be the company's focus is to ensure that the recommendations for improvements made can solve the problems they have.

a. Manage Service Request and Incidents (DSSO2)

For the aspect of managing company problems, it can be said to be quite mature, but it still needs to be improved further so that the DSS02 process can achieve the expected capability level targets to the maximum.

1) A priority matrix based on impact and level of urgency needs to be detailed and monitored for its implementation

2) There needs to be a classification of nuisance tickets, namely open, inprogress, solved and closed

3) It is necessary to separate and distinguish between recording requests and incidents

4) There needs to be an escalation form, namely handling incidents both internally and reaching third parties

5) Creating Log Problem Solving Knowledge (KEDB) which is part of the problem management process

b. Manage Problem (DSSO3)

For the aspect of managing company problems, it can be said to be quite mature, but it still needs to be improved further so that the DSS03 process can achieve the expected capability level targets to the maximum. 
1) There is a need for monitoring, control and evaluation of log problems

2) There needs to be an escalation form, namely handling incidents both internally and reaching third parties

3) Creating Log Problem Solving Knowledge (KEDB) which is part of the problem management process

4) Nuisance Logs are needed to identify any problems that result from recurring disturbances, including disturbances that require further investigation

\section{Conclusion}

From the results of the evaluation of IT governance performance at Insurance XXX can be concluded that:

1. There are 2 selected COBIT 5 processes related to the state of information technology governance in Insurance XXX, namely DSS02 and DSS03. For the value of maturity, there are two process at level 2 (managed), namely DSS02 (Manage Service Request and Incident) and DSS03 (manage problem).

2. The target value of the process capability expected by the company is level 3 (established), while the gap analysis results show that most of the selected processes have a gap of one level. To achieve the expected target level, companies can follow the recommendations for improvement with the COBIT 5 standard given by the author in the previous chapter.

\section{E. DAFTAR PUSTAKA}

[1] Chirani, E., \& Tirgar, S. M. (2013). Information Technology 's Role in Organization. Arabian Paper of Business and Management Reviews, 3(1), 16-23.

[2] Henrique, P. et al., 2014. Evaluating IT Governance Practices And Business

[3] Setiawan, A. K., \& Andry, J. F. (2019). IT Governance Evaluation using COBIT 5 Framework on the National Library. Jurnal Sistem Informasi, $15(1), \quad 10-17$. https://doi.org/https://doi.org/10.21609/jsi.v15i1.790

[4] Khadra H.A., Zuriekat M., and Alramhi N., 2009. "An Empirical Examination of Maturity Model as Measurement of Information Technology Governance Implementation." The International Arab Paper of Information Technology, vol.6, no.3, July 2009

[5] Weill, Peter \& Ross, Jeanne. (2004). IT Governance: How Top Performers Manage IT Decision Rights for Superior Results.

[6] Peterson, R. R. (2003). Information Strategies and Tactics for Information Technology Governance. In W. Van Grembergen (Ed.), Strategies for Information Technology Governance. Hershey, PA: Idea Group Publishing Procedia Technology, 16, pp.849-857.

[7] ITGI, 2003, Board Briefing on IT Governance 2nd Edition

[8] ISACA, 2012, COBIT 5: Enabling Process,. USA: IT Governance Institute.

[9] Putri, M. A., Aknuranda, I., \& Mahmudy, W. F. (2017). Maturity Evaluation of Information Technology Governance in PT DEF Using Cobit 5 Framework. Paper of Information Technology and Computer Science, 2(1). https://doi.org/10.25126/jitecs.20172123

[10] Sabatini, G., Setyohadi, D. B., \& Yohanes Sigit Purnomo, W. P. (2017). Information technology governance assessment in universitas atma jaya yogyakarta using cobit 5 framework. International Conference on Electrical Engineering, Computer Science and Informatics (EECSI), 4(September), 487-491. https://doi.org/10.11591/eecsi.4.1072

[11] Rahmigina Rooswati, Nilo Legowo (2018). Evaluation Of IT Project Management Governance Using Cobit 5 Framework In Financing Company. 2018 International Conference on Information Management and Technology (ICIMTech)

[12] ISACA, 2012, COBIT 5: Process Assessment Model,. USA: IT Governance Institute.

[13] Irmayansyah, Mrs, and Agustina R. Putri. "Pengukuran Tingkat Kematangan Simaster Menggunakan Cobit 4.1 di SMA Plus Bbs Bogor." Teknois, vol. 7, no. 1, May. 2017, pp. 47-58, doi:10.36350/jbs.v7i1.33. 